\title{
Career Motivation in the Process of State Regulation of Youth Employment
}

\author{
Natalya Stativka \\ Kharkiv Regional Institute of Public Administration of the National Academy of \\ Public Administration attached to the Office of the President of Ukraine, Ukraine \\ nstativka@ukr.net \\ https://orcid.org/0000-0003-0903-6256
}

\begin{abstract}
Anna Batiuk
Kharkiv Regional Institute of Public Administration of the National Academy of Public Administration attached to the Office of the President of Ukraine, Ukraine batiuk1990@gmail.com

https://orcid.org/0000-0003-2579-5578
\end{abstract}

Received: 4. 7. 2020

Revised: 16. 3. 2021

Accepted: 30. 3. 2021

Published: 29.11.2021

\section{ABSTRACT}

Purpose: The main objective of the study is to find new methods for the state promotion of career motivation in the process of providing youth employment.

Design/Methodology/Approach: To accomplish the research objectives, a set of mutually reinforcing general scientific and special research methods was used.

The basic statistical analyses of unemployment rate data according to the methodology of the International Labour Organization, while the level of registered unemployment (the national indicator of the unemployment rate in Ukraine) serves as an indicator of the State Employment Service performance.

Findings: A detailed analysis of career motivation theories and the technology of servicing potentially unemployed people helped justify the feasibility of applying a communicative and psychological method in employment center specialists' work with their clients, in particular the youth. Thus, a number of measures were identified and proposed in order to better encourage employment and increase the effectiveness of career motivation.

Practical Implications: In the course of the research, the development trends in the youth labour market of Ukraine were estimated, the main causes for youth unemployment were determined, and the value orientations and characteristics of modern youth were analysed. The importance of employment services focusing on effective communication with their 
clients to motivate them for successful employment and self-development is substantiated. The issues of young people's migration activity, which can have a negative effect on the economic development of the country and increase the socio-demographic risks to national security, need a detailed scientific study.

Originality/Value: Currently, the science of public administration does not pay due attention to the role of public institutions in providing career motivation or to the legal consolidation of the measures that motivate productive work. A vast majority of research works on professional motivation and career development were conducted by scientists from the fields of pedagogy, psychology and social economy. These works reveal the essence of pedagogical education and the peculiarities of human psychological influence, yet fail to define the role of the state as the main social institution which should lay the basis for youth development and encouragement to employment. This renders the topic of the present study relevant.

Keywords: unemployment, state regulation, state support, employment, youth, career motivation, vocational guidance, labour market.

JEL: J08, J13, J21, J64

\section{Introduction}

The social structure of the Ukrainian labor market under the conditions of transformational processes in the economic sphere is undergoing significant changes, which is manifested in the increased employers' workforce requirements, namely: high mobility, innovative approaches to performing labor processes and greater IT competence. Under these conditions, it is the active highly educated young people characterized by dynamism, creativity, technological skills, trainability, etc. who can strengthen significantly their competitive positions in the national labor market.

Although young people are the most active part of the employable population, when entering the labor market, they face certain difficulties, the key of them being discrepancy between the actually acquired professional skills and competencies and the level of training expected by employers; nonobjective assessment of own abilities, skills and capacities by job-seekers. This situation in the labor market has been brought about by the lack of effective interaction between its key actors: employers, educational institutions and the workforce. The problem is especially acute for the operation of the youth labor market. The absence of strategic forecasts for the structural development of the economy makes it impossible to form an adequate demand for training of specialists of certain qualification level and specialization; educators, in turn, without having close cooperation with employers, offer educational programs detached from the qualitative demand in terms of the necessary competencies and skills of graduates (focusing mainly on theoretical education); young labor force, when entering the labor market, is often forced to work in fields unrelated to the acquired profession. 
Given the above, the state as a social institution faces important challenges: creating favorable conditions for a decent youth employment and promoting a balance between labor supply and demand; supporting young people in their desire to work and build careers, providing qualified assistance in young people's vocational guidance and motivation for successful self-realization; providing conditions for finding the first job, taking into account the needs of young people and changes in their value orientation.

The main objective of the study is to find new methods for the state promotion of career motivation in the process of providing youth employment.

Based on the set objective, the article is structured as follows: the literature examining the aspects of career development and career guidance is considered; career motivation theories are generalized; the condition and prospects of the youth labor market development in Ukraine are assessed; the definition of 'the youth' and the reasons for youth unemployment are researched; a technology of services provided to young people by the specialists of employment centers is analyzed; the expediency of using the communicative and psychological method in the work of employment centers specialists with the population, in particular the youth, is substantiated; measures to improve the state regulation of employment services are proposed.

\section{Theory and method}

The results of the analysis of the labor market situation prove that there are challenges necessitating improvement of the mechanisms, technologies and methods of service activities of the state in the field of employment, including the introduction of new approaches to providing services to the unemployed and employers.

The Ukrainian labor market was reformatted under the pressure of socio-economic and political factors, the visa-free regime with Europe, the automation of many of production processes and the digitalization of society. The competition between employers is intensifying, while employees are looking for the best offer. Not only employers or job seekers compete with each other, but also recruitment agencies whose services are used by both business giants and small businesses when they are looking for the right specialists. Online services try to occupy their unique niche to meet the demands of a specific category of employees. In this difficult socio-economic environment, a priority task of public authorities' service activities is providing employment assistance on an expedited basis, implementing an individual approach to rendering services to customers, in the first place to the unemployed youth. These factors determine the need to improve the employment service technologies and methods, thus ensuring a well-established level of communication with the public and citizens' understanding of the need to stay sharp about their careers and to be aware of the benefits of legal employment.

One of the current priorities is to apply an individual approach to each person, providing prompt and high-quality employment assistance, first of all, to 
those categories of citizens who have additional employment guarantees. Additional opportunities for implementing this task are provided by the methods of career motivation of citizens.

That is to say, the need to improve the quality of service for job seekers and employers necessitates a change in the approaches of public authorities to their work in the field of employment, the application of a customer-based approach by professionals who provide employment services. Efficiency, individual approach and targeted services should become priorities in the process of improving the technology of the state employment service.

To accomplish the research objectives, a set of mutually reinforcing general scientific and special research methods was used, among them: methods of analysis and systematization of scientific data, provisions of legislative and normative documents - to clarify the level of scientific development of the researched problem and the level of its normative and legal support; identification of young people' values and priorities in the system of the labor market functioning; a semantic and etymological method - to determine the content of the basic research concepts; a synthesis of theoretical and empirical data - to identify the current state, problems and trends in the national labor market; a statistical method - to identify employment trends by age groups; system analysis and structural and functional analysis - for a comprehensive study of the quality of services provided by the state employment service as a service institution; the methods of abstraction, formalization, generalization - to develop recommendations for improving the technology of working with young people, including the methods of career motivation based on implementation of primary and in-depth profiling of job seekers; a comparative analysis of the obtained data - in determining and comparing progressive world practices of guaranteeing youth employment.

In this article, we used the data on the unemployment rate according to the methodology of the International Labor Organization, because it is an indicator used in Ukraine in accordance with international practices to measure the unemployment rate. At the same time, the level of the registered unemployment (the national indicator of the unemployment rate in Ukraine) serves as an indicator of the State Employment Service performance. The registered unemployment indicator includes those Ukrainians who applied to the State Employment Service.

Justification of the need to study a career development issue can be found in the works by A. Smith and F. Taylor. A detailed research into the issues of motivation and self-realization of the individual was done by A. Maslow (2008, p. 352), who proposed a hierarchy of human needs. The study of this theory was continuined by Frederick Herzberg (2007, p. 240) who found that wages do not make employees enjoy their work or motivate them, since a person gets work satisfaction when achieving results and recognition.

Further, an American scientist and Nobel Prize winner P. Diamond, researching the labor market proved that there exists a relationship between the du- 
ration of job search by an individual and the economic costs of the state. Thus, with increased time of searching for a job, workers lose their qualifications, motivation to work and its productivity (Rampell, 2010).

An important contribution to the study of the problem of professional motivation of young people in the modern economy was made by scientists $M$. Vachevsky, D. Zakatnov, M. Miropolska, L.Yershova, and others. V. Lozovetska (2014, p. 21), determining the conditions for career development, established the necessity of systematic improvement of professional knowledge and skills in accordance with specific working requirements. In other words, in the modern conditions, professional self-improvement, training, and skills development become permanent, going on throughout the entire labor activity and career development. In their work, S. Luchyk and M. Luchyk (2017, p. 43) explore the significance of an occupation for a person, linking it with the choice of lifestyle, justifying the importance of the correct career choice.

The results of the exploratory studies on the tools, approaches and methods of vocational guidance of young people are also discussed in the works of $L$. Avdieiev (2013), V. Skulska (2005), Yu. Marshavin (2014) and other researchers.

However, a vast majority of research works on professional motivation and career development have been conducted by scientists from the fields of pedagogy, psychology and social economy. These works reveal the essence of pedagogical education and peculiarities of psychological influence of man, yet without defining the role of the state as the main social institution which should lay the basis for youth development and encouragement to employment. Currently, the science of public administration does not pay due attention to the role of public institutions in providing career motivation or legal consolidation of measures that motivate productive work. This renders the topic of the present study relevant.

Globalization, political, economic, social, humanitarian, environmental challenges of today affect significantly the social component and daily life of people. The population is rethinking values, goals and ways to achieve them. Transformations also impact young people - the vector of their life priorities and commitments has changed, the motivation for a successful steady career has reduced.

As is well-known, the motivation of human behavior stems from people's values; that is why it is important to maintain national traditions, to raise children according to general moral norms and values.

Choosing a profession is a very complicated process that requires various motivational measures supposed to encourage professional self-determination and career development.

In modern science, there are many views on professional career, and a number of motivation theories have been developed. The most famous of them are: the bonuses and penalties theory; a psychodynamic model of career choice by E. Bordinthe hierarchy of needs theory by A. Maslow; the trait and factor 
theory by F. Parsons; A. Roe's theory of the origin of occupational interests; J. Holland's theory of career choice, E. Ginsberg's compromise with reality theory; D. Super's theory of career development. Let us consider each of these theories separately.

The theory of bonuses and penalties is the origin of the scientific doctrine of motivation. However, in modern science much controversy has been generated over imposing penalties for bad deeds, which destroy a desire to get to the top and make people look constantly for reward. This theory focuses primarily on the end result and does not take into account personal needs, so it can but supplement other concepts.

The psychodynamic theory of career choice claims that it is the interaction of consciousness, emotional state, and motivational forces which determines the behavior of the individual. The main postulate of the theory is the importance of finding pleasure in work, as well as in other fields (Bordin, 1963).

Maslow's theory (Maslow, 2008) of needs establishes a hierarchy of human needs, according to which a person, having satisfied the lower level needs receives an incentive to realize the higher needs for self-development, recognition and respect. Based on this hierarchy, the development of a person's employment career depends on their everyday needs.

Frank Parsons' theory of traits and factors is based on taking into account personal characteristics. The three main principles of a successful choice of profession according to F. Parsons (1909) are: a clear vision of one's individuality, inclinations, interests, abilities and talents; awareness of the requirements and conditions imposed by the labor market on a profession in order to build a successful career and be competitive; a reasonable combination of the first two principles in the course of making occupational choice.

Anne Roe's theory of the origin of occupational interests (1956) established that the relationship between parents and children leads to forming a child's attitudes, needs and interests, which is reflected, in particular, in their adult choice of profession. Thus, the researcher identified three types of child-parent relationships that generate professional interests in young people:

- the first type - parental overprotection - creates in the child the need for constant support and care leading to dependence on the opinion of others, which affects the choice of profession and professional activity;

- the second type - parents who do not pay enough attention to their children, trigger the children's strive after overachievement, focusing them on career and success;

- the third type - children whose parents love, accept, and encourage their independence, develop into full-fledged mature personalities.

Although Anne Roe's theory has not been fully substantiated, it has drawn researchers' attention to the role of the family and family traditions in career planning. At present, in international vocational guidance, a method that is gaining popularity is studying of family genograms of employment services 
clients. This method allows exploring professional stereotypes of a person, patterns of their family roles, attitudes to different statuses and professions.

J. Holland's theory of career choice (Holland, 1968) reveals a link between the type of personality and the sphere of professional activity. Based on the fact that people mostly choose a profession according to their interests, which allows them to realize their abilities and self-worth, J. Holland singled out six personality types: realistic, investigative, social, conventional, entreprising, and artistic. According to the theory of career choice, people who choose the field (kind) of activity in accordance with their personality type are more likely to succeed. The questionnaire of occupational orientation developed by the author is widely used in the vocational guidance in Ukraine.

E. Ginsberg's compromise with reality theory focuses on life-long career building. Thus, Ginzberg (1951) identifies three periods of vocational choice: 1) a fantasy period (up to 11 years) where the child plays out situations that reflect his/her initial occupational preferences, gradually becoming oriented professionally, e.g., playing scenes of animal treatment can guide the child to choose veterinary medicine; 2 ) a tentative/ hypothetical period (from 11 to 17 years) in which the stages of interests, abilities, values, and a transition stage are distinguished. In this period, a person is more aware of their professional paths, the requirements for professions, and has a deeper understanding of their career preferences; 3 ) a realistic period (from 17 years) - for the first time a person's world of professions is narrowed down to several possible options. Analyzing his/her abilities and professional interests, a person compromises and makes decisions about their future.

D. Super's theory of career development (Super, 1971) defines 5 professional development stages that a person goes through in their lifetime:

- the first stage - growth - starts at birth and lasts until 14-15 years, when the interests and inclinations of the individual are formed, and the self-concept development begins;

- the second stage - research - lasts from 15 to 24 years; during this period, the range of professional choices gradually decreases, the person undergoes professional training, receives practical professional knowledge and skills;

- the third stage - career-building - lasts from 25 to 44 years and is characterized by accumulation of professional experience;

- the fourth stage - preservation of the achieved - lasting from 45 to 65 years is based on preservation and sustaining of the available professional level and position;

- the fifth stage - decline - begins after age 65 , involving a gradual decline in professional activity and retirement.

The main postulate of D. Super's theory is to combine the development of a professional career with the development of the self-concept. 
The above theories of motivation and career development focus on the fact that the success in the professional development of young people depends not only on the situation of labor demand and supply, but also on a conscious concentration of the individual on effective development and formation of their own motives and professional values.

\section{Results}

In the face of the powerful challenges of our time, the question arises of providing the labor market with workforce in occupations of high demand. In the process of building careers, young people face the problem of lack of opportunities for decent employment and self-realization. Thus, finding effective state regulation methods for encouraging employment and measures to stimulate youth self-fulfillment with a focus on permanent active employment becomes an up-to-date issue.

The conducted literature review of the definition of 'the youth' shows differences in its interpretation by different scholars. Thus, an American sociologist K. Taylor (1999) refers to the youth young people aged 7-8 to 23 years. E. Schpranger (1957) determines the age limits of young people depending on gender: for girls, it is the age from 13 to 19 years, for boys - from 14 to 20 years.

The UN General Assembly defines young people as persons aged 17 to 25 between the end of childhood and the beginning of employment. The World Health Organization considers a person to be young till 44 years of age.

In Ukraine, according to the Law of Ukraine "On Promoting the Social Formation and Development of Youth in Ukraine", young people are citizens aged 14 to 35 .

Definitions of the youth differ not only in age, but also in the general understanding of the concept of 'the youth'. For instance, Yu. Shchotova (2006 p. $3-4$ ) defines young people as a special sector of society aged 14 to 28 years, whom the law provides with additional benefits and guarantees of employment, vocational training and labor activity in order to engage in productive social work in the period of initial social formation. Other scholars refer to young people as people under 30 who have not started independent labor activity and have not started a family of their own (Tihomirov et al., 1971).

Thus, young people differ from other workers both in age and in the peculiarities of their condition in the field of labor relations; in legal terms, the lower age limit for young people coincides with the age at which employment is allowed (15-16 years), and the upper age limit is 27-30 years. By this time, the biological formation of the body ends as well as the formation of professional interests and initial training in most young people who begin their careers; also, it is the end of the established additional guarantees for young workers (Vasilishina, 2009).

A modern young person over 30 is an adult who is mostly married with children and has started her independent life and work activity. In the life of 
every person, these events occur at different times, which complicates the establishment of the age requirement of the concept of a young person. But in general, the age limits vary between 14-16 years for the lower limit and between 25-35 years for the upper limit. In Ukraine, a person is considered young for twenty years, during which time young people go through various stages of life and need support. State regulation should be aimed at solving the problems of a specific group of people. Thus, without defining certain age groups, it is now impossible to build an effective mechanism for state promotion of youth employment. People aged 15-20 have problems and interests different from those of people aged 30-35. Based on this, it is expedient to divide young people into two separate categories: young people aged 15 to 25, and young people aged 26 to 35.

Youth is a driving force, the source of development of the state and society, and it is young people's self-fulfillment and career success that determine the future of the country and the entire world. The younger generation has rather an ambiguous attitude to commonly agreed values. There is a perception that some stereotypes and moral norms are not suitable for the modern world, respectively, the youth go against them.

A desire for earning their living is natural to the current younger generation; however, some young people prefer fast types of earnings with daily or weekly wage payment. There is a tendency among young people to work and earn here and now. In this view, it is important to accelerate the job seeking procedure, apply the latest IT tools for job search and conduct constant monitoring of vacancies.

During the study, the authors determined the characteristic features of the modern young person are: mobility, creativity, innovation, social maladaptation, impulsiveness, ambition, determination, sensitivity, name but a few.

The study of the social behavior of young people shows that they are not stress-resistant, although having sufficient endurance, and differ from the older generation in their diversity of interests and views.

Professional self-determination and self-realization of young people impact the formation of their life values and prospects (starting a family, material well-being, self-esteem, lifestyle, etc.). Thus, choosing a profession, a person chooses a certain life map - what professional group he or she wants to belong to, what status to achieve.

The main attributes of a successful person today are dynamism, mobility, ability to work in a variety of fields, proficiency for several professions and broad basic knowledge. This creates new challenges for the state, in particular for employment centers. Thus, there is a need to match the services provided by employment centers to the new requirements of the time, focusing on the values, interests and goals of clients, encouragement, motivation and support of their professional development and well-beingln most countries of the world, tension in the field of youth employment is building. Almost 71 million young people around the world are jobless. In general, young people 
aged 15 to 24 make up about 16\% of the world population, which equals to 1.2 billion people. Without an active labor participation of the young population, the foundation of economic development is being destroyed, and the possibility of achieving a sustainable development pace in all countries of the world is undermined.

A similar situation is observed in Ukraine. For example, in 2019, 337.4 thousand young people were qualified as unemployed, which amounted to $33 \%$ of the total number of unemployed people. Of these, almost 283 thousand young people (84\%) could find employment.

Based on the fact that young people are one of the most important components of the national labor market, the situation there depends on its development and formation. The vast majority of young people seek self-realization, want to work and earn an income. This confirms the relatively high level of economic activity of young citizens. The employment and unemployment rates are qualitative indicators of the effectiveness of the labor market regulation by the state. During 2010-2019, the labor market was generally quite stable in terms of unemployment, with some downward trend (Fig. 1).

Figure 1: Dynamics of employment and unemployment rates (according to the International Labour Organisation methodology) in Ukraine, 2010-2019

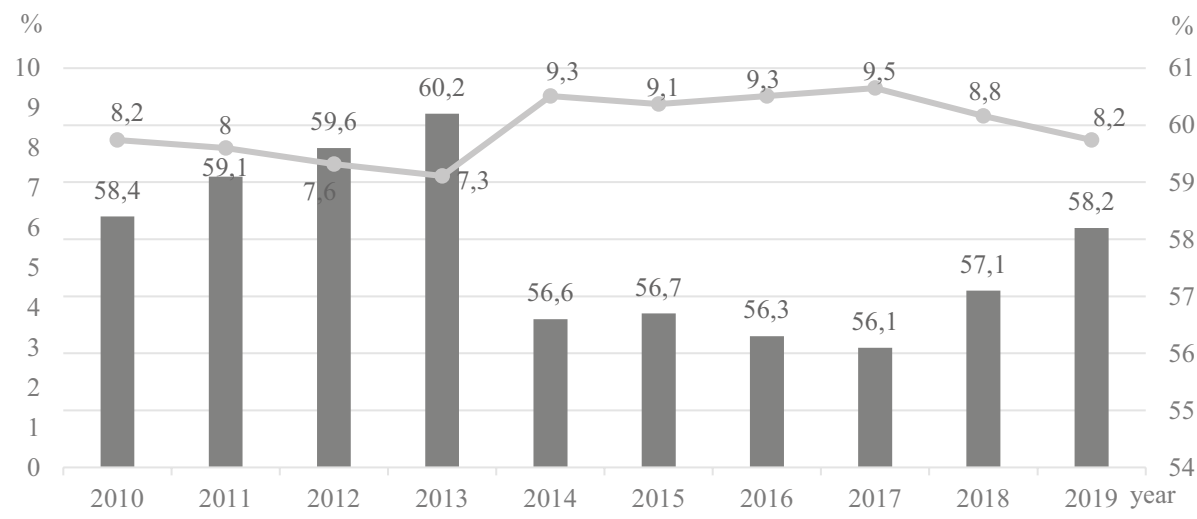

Source: authors' estimations based on data from the State Employment Service of Ukraine

The peaks of the national labor market deterioration in 2014-2017 were associated with the difficult political and socio-economic situation, the military conflict in Eastern Ukraine. From 2018, the unemployment rate is declining. It is during this period that active work is being carried out to promote the employment of internally displaced persons (IDPs), and new methods and approaches to working with cllients are being introduced into the activities of employment services. For instance, in the period of 2015-2018, the State Employment Service provided services to 101 thousand IDPs, of which: 29.6 thousand were employed, 9.4 thousand were trained, 10.1 thousand took part in public works and other contingent work. In 2018, due to compensa- 
tion to employers for labor costs of employing the registered unemployed IDPs, 1.1 thousand people could get their jobs. (Ukraine Migration Profile for 2018, 2019, p. 94).

Against the national trends, labor market instability and rather sharp fluctuations in the employment rate, the problem of youth employment has become especially acute.. Young people who are the bearers of new knowledge, in case they cannot get a job within the national labor market, will focus on seeking work in foreign markets. According to a survey conducted by Kyiv International Institute of Sociology (April 2018), 7\% of the adult Ukrainians were planning to go abroad in the next six months for a long stay: work, study or emigration (Migration mood of the population of Ukraine near 2018, 2019). According to the research of Yu. Mostova and S. Rakhmanin (2018), when asked 'Are you ready to leave the country?', 17\% of respondents expressed their readiness to leave. The effect of such migration processes may be a future loss of labor potential and staff gaps, crippling the country's sustainable economic development.

The number of economically active population decreases in Ukraine every уеаг (Figure2).

For example, in 2019 the number of employed population decreased by almost 100 thousand people compared to 2016. The sharp decline in the number of the employed, observed from the beginning of 2016 to 2018, was due to a demographic crisis and the unstable economic situation in the country. An influential factor in reducing the number of both the employed and unemployed people in Ukraine was the introduction of a visa-free regime with the European Union in 2017.

Figure 2: The number of the employed population in Ukraine in 2016-2019

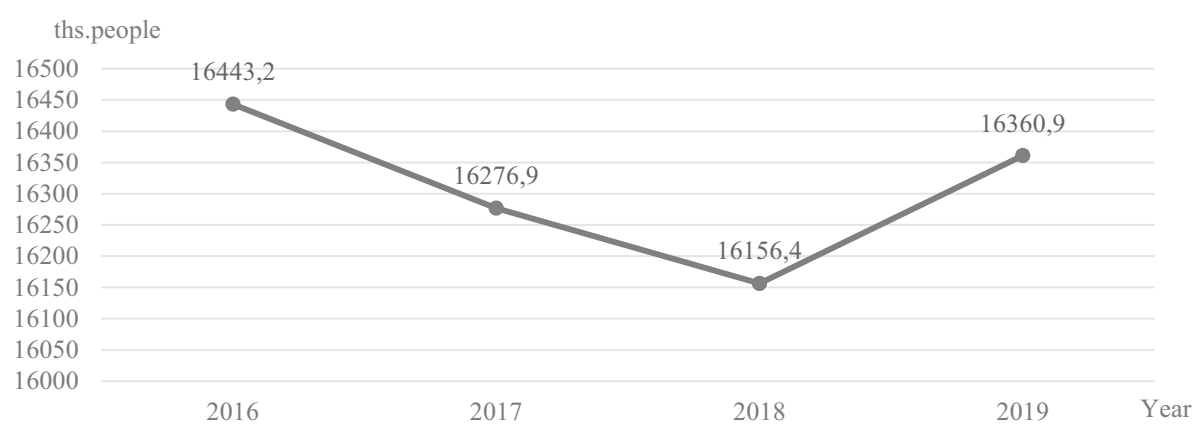

Source: authors' estimations based on data from the State Employment Service of Ukraine

As a result, the number of people willing to work abroad increased, which led to a higher rate of external migration to the neighboring countries and a reduction in the workforce per job in the Ukrainian labor market. Among the factors that motivate the population for labor migration are high overseas wages and living standards compared to those in Ukraine. In particular, ac- 
cording to the State Statistics Service of Ukraine, the average wage in 2019 was about $\$ 400$ per month, which is almost three times higher than the country's minimum wage, yet, 3-4 times lower than the average wage in most EU countries.

Migration of the Ukrainians is not a new phenomenon. Prior to the introduction of the visa-free regime with the European Union, a significant part of the population was in labor migration abroad. The abolition of the visa requirements and introduction of free cross-border transit have become an additional impetus for the migration of young people abroad. In general, among age groups, people aged 15 to 35 migrate the most.

Figure 3: Dynamics of the migration of the population of Ukraine by age groups from 15 to 64 years of age, 2014-2018

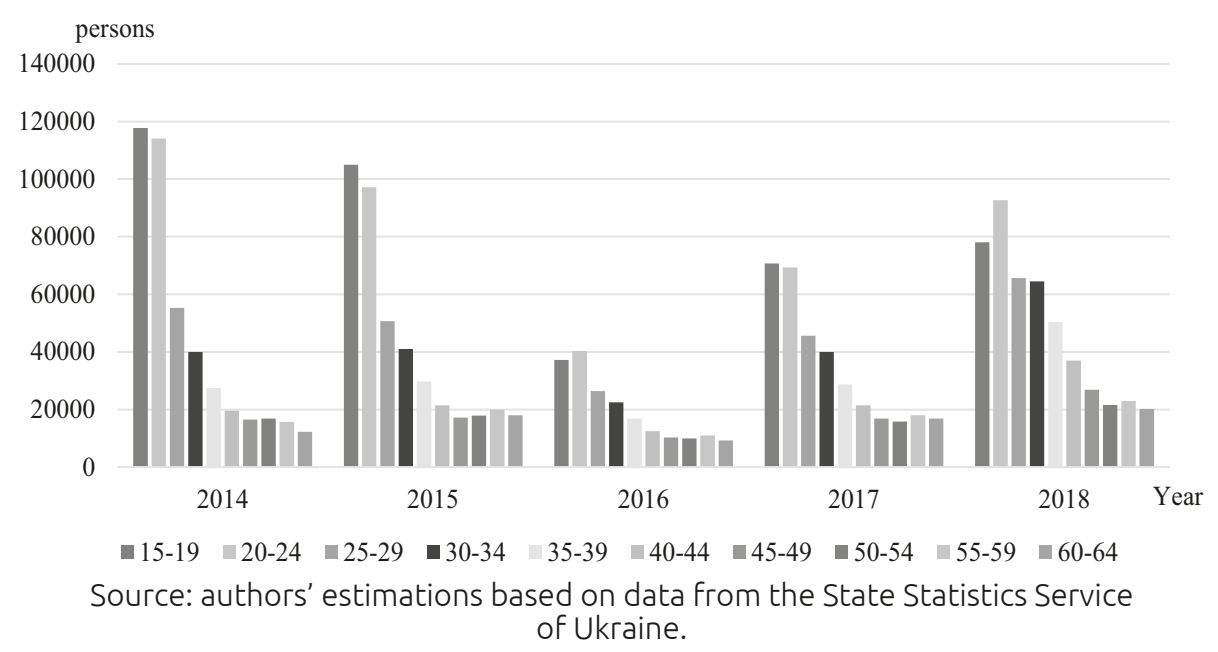

The number of people traveling abroad during 2014-2018 was consistently high. Among all age groups, the highest number of migrants is observed among people aged 15 to 24. Most often, migrant workers are from rural areas, which affects negatively the demographic situation in the countryside. Moreover, a significant number of migrants have vocational or complete secondary education; therefore, their migration causes a significant damage to the national economy of Ukraine. By spending money on youth education and training, the state makes a large financial contribution to its future economy, hoping for further development of these funds by young people for the benefit of Ukraine - by payment of taxes, filling vacancies in the national labor market, labor renewal. With young people migrating abroad, there is a huge outflow of workforce, and hence a loss of the state funds invested in the education and vocational training of these people, which has a negative impact on both the national labor market and the country's economy as a whole. Thus, the imbalance between the demand for labor and its supply increases, the labor market shrinks, giving rise to deficit of workers. On the other hand, inexperienced people are uncompetitive in the foreign labor market and have low employment opportunities. 
As for young people migrating to study abroad, it could be quite positive for Ukraine, since gaining the latest knowledge and international practical experience is beneficial for our country in terms of implementing innovative ideas, provided these persons return to Ukraine and get employed in their acquired profession. However, today's youth regard obtaining education and a degree in the European Union as an opportunity to work in the foreign labor market and apply for permanent residence.

Basically, in the recent years the level of youth unemployment in Ukraine has remained consistently high compared to other age groups. Unemployment affects people aged 15-24 more than other age groups.

Figure 4: Dynamics of unemployment rates in Ukraine by age groups aged 15 to $70,2014-2019$

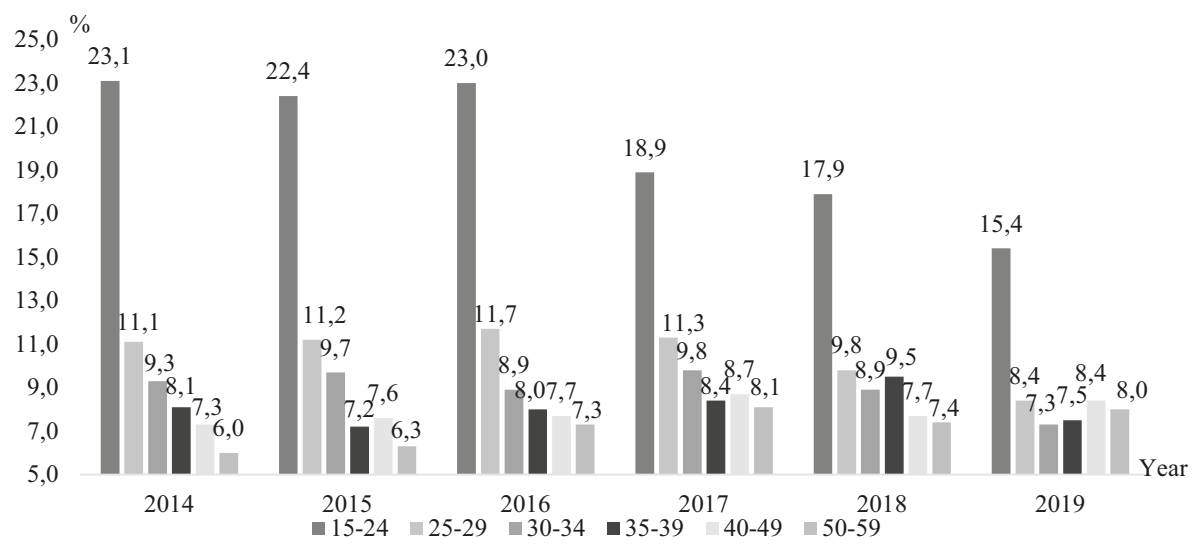

Source: authors' estimations based on data from the State Statistics Service of Ukraine.

In 2017, the share of unemployed youth among the total number of the unemployed in the labor market exceeded 36\%. Accordingly, the employment rate of persons aged 15-24 in Ukraine is the lowest, and in 2019 this figure dropped to $30.6 \%$.

The unemployment rate during 2014-2019 tended to decrease. While in 2014 the unemployment rate among people aged 15-24 was the highest and amounted to $23.1 \%$ of this age group, in 2019 it dropped to $15.4 \%$.

In general, 100.4 thousand young people had the status of the unemployed in 2019, which is by 6 thousand less than in the previous year.

There was also a strong correlation between a decrease in the unemployment rate and an increase in the age of workforce. Specifically, in 2018, the lowest unemployment rate was $7.4 \%$ among people aged 50-59, which is almost three times less than the unemployment rate among those aged 1524 (17.9\%). However, in 2019 this trend changed somewhat. Although the highest unemployment rate remained among people aged 15-24 (15.4\%), the lowest unemployment rate was recorded for the $30-34$ age group (7.3\%). 
Among the unemployed under the age of $35,85 \%$ had professional experience prior to registration with the employment service, which testifies to young people being oriented towards active employment.

Increasingly, young people receiving education seek help in finding part-time employment - after school hours, or during holidays, or on weekends, rather than a regular job. Thus, the problem of youth unemployment in Ukraine, as well as worldwide, caused by changing priorities and values of people, is becoming more and more urgent.

People over 25 are considered to be the most economically active in Ukraine. At the same time, the least competitive in terms of employment are young people aged 15 to 24, mostly lacking professional education and work experience ${ }^{1}$.

In 2019, 12.6 thousand graduate students benefited from the services of the State Employment Service, including 9.6 thousand university graduates and 3.0 thousand graduates of vocational schools. The number of appeals of young professionals for help in employment, when seeking their first job, indicates a gap between the existing supply of jobs and the demand for workforce of certain professional background.

Every year new cohorts of graduate students enter the national labor market in the conditions of uncoordinated operation of the key market actors, which leads to increased vocational imbalance and poses a major obstacle to effective youth employment.

The analysis of the employment rates of graduates of higher, vocational and general-education institutions who were registered with the employment service during 2018-2019 showed that the unemployed status is granted mostly to higher educational institution graduates. In particular, the employment rate among university graduates is lower than that of vocational school graduates, which can be attributed to the shortage of workers of nonprofessional occupations in the labor market (Table 1).

Among the graduates who had the unemployed status in 2019, 4037 people were employed, including: vocational school graduates - 1054 people (employment rate - 34.74\%); graduates of higher educational institutions - 2983 people (employment rate $-31.2 \%$ ).

1 According to the economic activity of the population of Ukraine for 2018. 
Table 1: Dynamics of the employment of university graduates (\%), who applied to the Employment Service and got the unemployed status, 2018-2019

\begin{tabular}{|c|c|c|c|}
\hline Year & Indicators & $\begin{array}{l}\text { Vocational } \\
\text { school } \\
\text { graduates }\end{array}$ & $\begin{array}{c}\text { Higher educational } \\
\text { institution } \\
\text { graduates }\end{array}$ \\
\hline \multirow{3}{*}{2018} & $\begin{array}{l}\text { Total number of people who } \\
\text { had the unemployed status }\end{array}$ & 2513 & 12392 \\
\hline & Found employment & 744 & 3585 \\
\hline & Employment rate & 29.61 & 28.93 \\
\hline \multirow{3}{*}{2019} & $\begin{array}{l}\text { Total number of people who } \\
\text { had the unemployed status }\end{array}$ & 3034 & 9560 \\
\hline & Found employment & 1054 & 2983 \\
\hline & Employment rate & 34.74 & 31.2 \\
\hline
\end{tabular}

Source: authors' estimations based on data from the State Employment Service of Ukraine.

In 2019, the total number of unemployed graduate students decreased compared to 2018, and the employment rate rose; to some extent, that was due to the approval of a new method for servicing of employment service clients.

Since 2018, the State Employment Service of Ukraine has changed its approach to servicing clients and introduced several new services. In particular, the Cabinet of Ministers of Ukraine approved "Methodology for the implementation of primary and in-depth profiling of job seekers and registered unemployed", which applies an individual approach to providing services, a primary profiling of personal needs of clients. A new category of 'career counselor'was introduced. The functional duties of career counselors include assisting citizens in realizing their strengths, helping them to make self-assessment of their competitive advantages, abilities and skills, and assistance in writing individual employment plans.

The duty of career professionals is to teach citizens to seek jobs, prepare for a job interview and create an effective resume independently. An important service provided by career counselors is to support clients in making career decisions, help in developing a long-term professional growth plan, motivate clients to achieve their goals. 


\section{$4 \quad$ Discussion and conclusions}

The rapid changes of the modern world necessitate creation of new conditions for professional growth. In order to bring the professional skills of jobseekers as close as possible to employers' demands, expand their competencies and increase the level of competitiveness, the State Employment Service of Ukraine provides vocational training to workforce on request of their employers. In 2019, 37.9 thousand unemployed people under the age of 35 were trained. This measure has proved quite effective, because the order for vocational training is formed on the basis of specific needs of employers with a subsequent guarantee of $100 \%$ employment upon graduation.

The effectiveness of implementing state employment policy largely depends on management entities' understanding of the fundamental needs of the modern youth and their social positions. Presently, employment promotion programs are not fully implemented, being mostly declarative in nature, as reflected in deterioration of the key indicators of management objects condition, namely the inconsistency of elements of the labor market and its imbalance.

In this respect, the study of the latest methods and approaches to servicing clients by the Employment Service is becoming relevant.

In the course of organizing career counseling for young people, the emphasis should be made on motivation. Encouraging work, motivation is a key factor for effective and successful professional activity. Youth counseling should be based on the existing motivation theories. It is necessary to influence young people's behavior and activities, based on their motivations to work.

The methodology of career counseling, which is currently used by the State Employment Service of Ukraine, is designed to form and develop the individual psychological qualities of people. For professional growth of the individual, evolving their labor and creative capacities, motivation and reflective self-organization in forming professional competence are of particular importance. The survey of the existing theories of professional development and motivation has helped to conclude that each person makes their own professional life. Thus, career counseling in employment centers should be based on the principles and methods of occupational motivation, with a special focus on communicative and psychological aspects of working with clients.

The core of a communicative and psychological approach is effective communication in servicing clients. This involves building trust in relations between an employment service specialist and a client, providing a favorable atmosphere of interaction which encourages the client's awareness and development.

In the course of communication, the career counselor must guide the client to self-identification. In this way, the client should determine the future upper limit of his/her career and have a clear understanding of their own professional growth plan. In this aspect, the main principle in communication of the career counselor with the employment service client should be active listening. This method allows exploring the client's psychological state, encouraging him or her to express their desires and goals more openly. 
Young people's successful vocational realization in the labor market requires psychological support for forming their self-concept and defining career orientation. The state should provide coordinated work to help young people respond quickly and adequately to socio-economic changes and acquire quickly new skills and competencies.

The key role in the initial counseling should be given to young people's awareness and evaluation of their employers' requirements, and to analysis of the labor market situation. While conducting the initial survey, the career counselor should ask the client the questions: 'What is the ultimate goal of your professional development or career?' and 'How to achieve it?'

For an active professional development and fulfillment of personal career goals, it is important that young people should be aware of their individuality and uniqueness. Based on this, it is necessary to establish the compliance of their personal characteristics with the requirements of the chosen vocational activity and systematic upgrading of their professional qualities and skills. This has become possible with a successful launch of a test version of the educational portal of the State Employment Service.

Thus, among the European countries that are members of the European Union, the Youth Guarantee programme has been introduced, which obliges the state to provide young people with quality offers for employment, continuing education, and internships. As part of youth employment support, the states create interest-free loans to support small and medium-sized businesses, provide subsidies and bonuses for the admission of young people for internships and employment.

Countries around the world are actively implementing innovative methods of work with job seekers and employers, including many useful up-to-date services. In accordance with the world trends, transition of society to hightech information economy, Ukraine is also forming its national innovative system of management. Smart technologies for providing social services to the population are being developed. To implement the state employment policy even more effectively, innovative solutions should be implemented promptly - that is a requirement of society and time. In this respect, a number of measures are proposed to improve the services of the State Employment Service of Ukraine, provided, in particular, to young people.

Given that the majority of young people study alongside employment, there is a significant demand for part-time, temporary work, weekend and vacation jobs. Seeking a job takes a lot of time and effort. Innovation and dynamism being the distinguishing features of today's youth, new measures to provide employment services are needed. In view of this, it is appropriate to create mobile applications of the State Employment Service and vocational education centers; to introduce bots in messengers for a quick search for vacancies available at the moment, with the possibility of subscription and receiving newsletters on the labor market demand for specific specialists and labor force to perform certain types of work. 
Considering the very significant labor market demand for people of working professions, the number of higher education institution graduates seeking employment assistance, and focusing on the expressed desire of young people to work, it would be appropriate to introduce production training centers at secondary schools. The state needs to approve legislatively the introduction of training and production plants at secondary schools. This will allow young people to get a working profession by the time of receiving a high school certificate, which would increase their competitiveness in the labor market and give them opportunity to find employment in high-demand professions. In conclusion, we should note that changes in the world economy significantly affect the functioning of national labor markets and formation of professional careers of economically active population. The key factor is the compliance of the quality of the available workforce with the requirements of employers who determine career guidelines, professional criteria and competencies of employees.

The modern socio-economic transformations in the labor market are changing the realm of professions, reducing demand for specialists in some professions, while increasing competition between representatives of others. Crises in the labor market operation are manifested in the form of imbalance. This pattern of development is intrinsic to the labor market of Ukraine. A significant part of the youth segment of the labor market cannot find a job independently and seek help from employment centers. At the same time, being given the unemployed status, young people can feel stress, depression, and have low self-esteem. In this context, the tasks of the employment service professionals are to stimulate individuals to progressive development, raising their motivation for successful careers. Quality services and professionalism of employment service specialists, helping clients navigate in the labor market, form their сагеer plans and goals of professional activity, are becoming urgent to promote youth employment today.

In this regard, the state should provide an opportunity to train career counselors in the specifics of working with young people and people who need help in career planning and development. The financial component is important in this matter. In 2019, vocational training and career counselors were trained only in some regions of Ukraine, which cost about 392,000 Hrv $(\$ 14,000)$. However, in 2020 the state has not provided funding for these costs ${ }^{2}$. Ensuring these costs is necessary, given the importance of quality and qualified career motivation and planning of employment service clients.

Dividing the youth into two categories from 15 to 25 years and from 26 to 35 years, proposed by the authors above, also requires delimitation of the vectors of state assistance depending on the needs of each age group. In the field of promoting career motivation of persons aged 15 to 25, the state should actively pursue career guidance measures, in particular, approve the introduction into secondary education of a position of a career guidance specialist who will continuously work with students and analyze the development

2 For the data of the state site https://prozorro.gov.ua/ accessed 1 october 2020 
of their skills, preferences and competencies, arrange events and field visits to get acquainted with the range of professions. At the national level, it is necessary to create measures to promote internships for young people receiving training by giving subsidies to those employers who provide youth internships. An important method of state promotion of career development is to encourage employers to hire people without work experience to work at their first jobs by providing tax benefits or exemption from certain charges, taxes. A successful and quick start to work immediately after graduation has a great impact on the successful development of further professional careers.

State promotion of career motivation of people aged 26 to 35 should include a number of measures such as: promotion of career growth of young people through further training; assistance in staff rotation ensuring the development of skills and competencies; supporting youth self-employment by implementing public lending for development and support of business, creating business incubators and financing startups.

The importance of employment services focusing on effective communication with their clients, aimed to motivate them for successful employment and self-development, is substantiated.

The issues of young people's migration activity, which can affect negatively the economic development of the country and increase the socio-demographic risks to national security, need a detailed scientific study. In this regard, searching for new approaches to state regulation of these processes is particularly relevant. 


\section{References}

Avdeev L. and Ortikova N. (2013). Professional orientation of unemployed citizens and youth: teaching method. development. Kyiv: IPK DSZU, p. 55.

Bordin E., Nachmann B. and Segal S. (1963). An articulated framework for vocational development. Journal of Counseling Psychology, 10, pp. 107-116.

Economic activity of the population of Ukraine 2018 (2019). Stat.zbirnik. State Statistics Service of Ukraine. At <http://www.ukrstat.gov.ua/druk/publicat/ kat_u/2019/zb/07/zb_EAN_2018.pdf>, accessed on 31 May 2020.

Herzberg F. (2007). Motivation for work. Moscow: Peak, p. 240.

Holland, Y. (1968). Explorations of a theory of vocational choice. Journal of Applied Psychology, 52(1).

Ilich L. and Sarioglo V. (2019). Statistical modeling of skills mismatch in the labor market. Demography and Social Economy, 4 (38), pp. 42-57. https://doi.org/ 10.15407/dse2019.04.042.

Lishtva O. (2018). Migratsiyni mood of the population of Ukraine near 2018. At <https://www.kiis.com.ua/?lang=ukr\&cat=reports\&id=765\&page=1>, accessed on 28 May 2020.

Lozovetska V. (2014). Methodological approaches to career formation of future specialists. Scientific Bulletin of the Institute of Vocational Education of the National Academy of Pedagogical Sciences of Ukraine. Ser.: Professional pedagogy, 8, pp. 21-27. At <http://nbuv.gov.ua/UJRN/Nvipto_2014_8_5>, accessed on 31 May 2020.

Luchyk S. and Luchyk M. (2017). Problems of youth motivation for professional development in conditions of crisis. Visnyk of Chernivtsi Trade and Economic Institute. Economic sciences, 4, pp. 35-45. At <http://nbuv.gov.ua/UJRN/ Vchtei_2017_4_5>, accessed on 31 May 2020.

Marshavin Y. (2014). Ways to ensure the consistency of training in educational institutions of Ukraine with the needs of the labor market: methodological and applied aspects. Labor market and employment: production-practice. Science. magazine. Kyiv: IPZ DSZU, 3, pp. 13-18.

Maslow A. (2008). Motivation and personality. St. Petersburg: Peter, p. 352.

Miropolska M. (2004). Career guidance as a basis for forming and building a professional career. Institute prepared state staff employment services of Ukraine, 2, pp.17-19.

Mostov J. and Rahmanin S. (2018). Why Ukrainians leave their country. Dzerkalo tizhnya from 27.09.2018. At <https://dt.ua/internal/krovotecha-chomuukrayinci-pokidayut-svoyu-krayinu-267394_.html>, accessed on 31 May 2020.

Oliinyk, O. et al. (2020). Alternative methodology for assessment of youth competitiveness in the labor market of Ukraine. Management Science Letters, 10 (10). https://doi:10.5267/j.msl.2020.3.021

Parsons F. (1909). Choosing a vocation. Reprinted in 1989, Garrett Park, MD: Garrett Park Press, p. 5.

Public procurement indicators for 2019 and January-September 2020 (2020). At <https://prozorro.gov.ua/>, accessed on 1 October 2020.

Rampell C. (2010). Economists Share Nobel for Studying Job Market. At <https:// www.nytimes.com/2010/10/12/business/economy/12nobel.html>, accessed on 31 May 2020.

Resolution of the Cabinet of Ministers of Ukraine (2018). Methodology for the implementation of primary and in-depth profiling of job seekers and 
registered unemployed from 19. 9. 2018, 792. At <https://zakon.rada.gov.ua/ laws/show/792-2018-\%D0\%BF>, accessed on 31 May 2020.

Roe A. (1956). Early determinants of vocational choice. Journal of Counseling Psychology, 4, pp. 212-217.

Schpranger E. (1957). Psychologie der Jurendalters.

Shchotova Y. (2006). Legal regulation of youth employment in Ukraine, pp. 19-20.

Skulska V. (2005). Social partnership in the system of professional navigation for unemployed. Trade Union of Ukraine, 3, pp. 25-26.

Super, D. E. (1971). Occupational psychology. London: Tavistock, 209, p. 22.

Taylor C. (1999). Youth Culture and Youth Violence: Family and Child Ecology.

The Law of Ukraine (1998). About social development and development of young people in Ukraine from 5.02.1998, 2998 (7). At <https://zakon.rada. gov.ua/laws/show/2998-12>, accessed on 31 May 2020.

Tikhomirov N., Gordon L. and Klopov E. (1971). Study of the lifestyle of workers and some issues of social planning. The working class and the modern world, 1, pp. 99-112.

Ukraine Migration Profile for 2018 (2019). State Migration Service of Ukraine, p. 94.

Vachevsky M. (2012). The essence of competencies in the educational process and the competence approach in vocational education. Youth and the market, 8, pp. 25-32. At <http://nbuv.gov.ua/UJRN/Mir_2012_8_7>, accessed on 28 May 2020.

Vasilishina S. (2009). Special features of the sovereign regulation of the market for young people. Economy and power, 3, pp. 91-94.

Yershova L. (2018). Transformation of the system of values of academic and student youth in the context of reforming professional education. Naukovi novini. News Institutu profesiyno-tehnichnoï osviti NAPS of Ukraine. Professional education teacher, 16, pp. 162-168. https://doi. org/10.32835/2223-5752.2018.16.162-168.

Yershova L., Orlov V. and Zakatnov D. (2017). Methodical principles of professional orientation and counseling on the professional career of student youth. Scientific support for the development of education in Ukraine: current issues of theory and practice (to the 25th anniversary of the NAPS of Ukraine): Coll. Science. wash, pp. 291-297. 